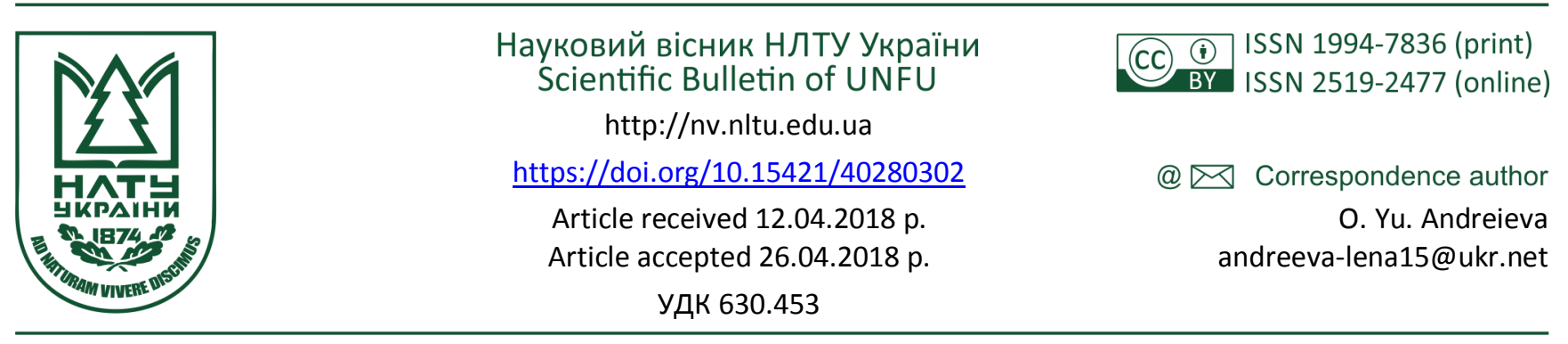

О. Ю. Андреєва, А. І. Гузій, А. В. Вишневський

Житомирський національний агроекологічний університет, м. Житомир, Україна

\title{
ПОШИРЕННЯ ОСЕРЕДКІВ МАСОВОГО РОЗМНОЖЕННЯ КОРОЇДІВ У СОСНОВИХ НАСАДЖЕННЯХ РІВНЕНСЬКОГО ПОЛІССЯ
}

\begin{abstract}
Досліджено особливості поширення усихання сосни звичайної (Pinus sylvestris L.) в осередках верхівкового (Ips acuminatus (Gyllenhal, 1827)) та шестизубчастого (Ips sexdentatus (Boerner, 1767)) короїдів (Curculionidae, Scolytinae) у лісах Державного підприємства "Володимирецьке лісове господарство" Рівненського обласного управління лісового та мисливського господарства. Встановлено, що площа всихаючих соснових насаджень лісгоспу впродовж 2017 р. збільшилася і перевищила 2000 га на кінець року. Частка площі осередків короїдів у площі всихаючих соснових насаджень зросла від 3,1 \% у першому кварталі до $75 \%$ у другому, до 90,8 \% у третьому та до 100 \% у четвертому. Виявлено, що чисті соснові насадження становлять 50,3 \% від площі всіх насаджень лісгоспу, в котрих сосна є головною породою, і 64,6 \% від площі осередків короїдів. З'ясовано, що у віковій структурі соснових насаджень лісгоспу на V-VIII класи віку припадає 61,1 \% від площі всіх соснових насаджень і 90,9 \% від площі осередків короїдів. Розраховано, що середня зважена повнота соснових насаджень лісгоспу становить 0,73 одиниці, а в осередках короїдів - 0,7 одиниці. Статистично підтверджено приуроченість осередків короїдів до чистих середньоповнотних соснових насаджень V-VIII класів віку.
\end{abstract}

Ключові слова: всихання; склад; вікова структура; повнота.

Вступ. Стан лісів погіршується у різних регіонах (Colombari et al., 2013; Koval' et al., 2015; Turko et al., 2016; Andreieva, 2016, 2017; Meshkova, 2017; Vyshnevskyi, \& Turko, 2018) під впливом зміни клімату, коливання рівня грунтових вод і антропогенного навантаження. Ліси Полісся, які ростуть у зоні надмірного зволоження, не встигають адаптуватися до зміни рівня грунтових вод (Koval' et al., 2015), а підвищення температури повітря (Balabukh et al., 2013) створює умови для активізації стовбурових шкідників (Meshkova et al., 2015, 2017).

Найбільші переваги мають шкідники, спроможні розвиватися у декількох поколіннях на рік, зокрема короїди верхівковий Ips acuminatus (Gyllenhal, 1827) i шестизубчастий Ips sexdentatus (Boerner, 1767)) (Curculionidae, Scolytinae) (Meshkova et al., 2017).

Завдяки доволі високій вологості повітря повільніше висихають гілки та лісосічні залишки, заселені цими шкідниками, що сприяє їхнім виживанню та розмноженню (Meshkova et al., 2017), а також розвитку офiocтомових грибів, які переносять ці комахи (Davydenko et al., 2017).

Поширення та розвиток осередків усихання насаджень вивчають у різних регіонах Полісся. Так дослідження у насадженнях сосни звичайної ДП "Жито- мирське ЛГ" довели, що осередки всихання приурочені до свіжого субору, чистих насаджень віком понад 70 років і переважно з низькою повнотою (Andreieva \& Zymaroyeva, 2016; Andreieva, 2017). У лісовому фонді Рівненської (Turko et al., 2016) та Волинської (Vyshnevskyi \& Turko, 2018) областей проаналізовано динаміку площ осередків деяких хвороб і шкідників лісу, але вивченню особливостей поширення осередків усихання соснових насаджень, заселених короїдами, у цих областях не було приділено уваги.

Об'єктом дослідження обрано Державне підприємство "Володимирецьке лісове господарство" (ДП "Володимирецьке ЛГ") Рівненського обласного управління лісового та мисливського господарства, лісовий фонд якого є одним із найбільших в Україні (77,1 тис. га), а природні умови $€$ сприятливими для вирощування лісів. Водночас останніми роками стан насаджень погіршився. Так площа вибіркових і суцільних санітарних рубок у лісовому фонді лісгоспу у 2016 р. становила 836 га, у 2017 р. - 2100 га. Найчастіше потерпають соснові ліси (Pinus sylvestris Linnaeus 1753), площа яких перевищує половину лісового фонду лісгоспу, причому переважають чисті насадження або з незначною домішкою листяних порід.

\section{Інформація про авторів:}

Андреєва Олена Юріївна, канд. с.-г. наук, доцент, кафедра експлуатації лісових ресурсів. Email: andreeva-lena15@ukr.net; https://orcid.org/0000-0003-0851-800X

Гузій Анатолій Ількович, д-р с.-г. наук, професор, завідувач кафедри експлуатації лісових ресурсів. Email: guziyai@ukr.net; https://orcid.org/0000-0002-8395-5333

Вишневський Анатолій Васильович, канд. с.-г. наук, доцент, кафедра таксації лісу та лісовпорядкування. Email: vishnev.tolik@ukr.net https://orcid.org/0000-0001-5381-1219

Цитування за Дсту: Андреєва О. Ю., Гузій А. І., Вишневський А. В. Поширення осередків масового розмноження короїдів у соснових насадженнях Рівненського полісся. Науковий вісник НлТУ України. 2018, т. 28, № 3. С. 14-17.

Citation APA: Andreieva, O. Yu., Guzii, A. I., \& Vyshnevskyi, A. V. (2018). Spread of Bark Beetles Foci in Pine Stands of Rivne Polissya. Scientific Bulletin of UNFU, 28(3), 14-17. https://doi.org/10.15421/40280302 
Мета досліджень - виявити особливості поширення осередків усихання сосни, заселеної короїдами, у лісах ДП "Володимирецьке ЛГ".

Матеріали і методи. Дослідження проведено шляхом статистично-порівняльного аналізу бази даних лісового фонду ДП "Укрдержліспроект", матеріалів лісопатологічних обстежень соснових насаджень лісового фонду ДП "Володимирецьке ЛГ" (Methodical recommendations, 2011) та статистичної звітності стосовно площі санітарно-оздоровчих заходів у цьому лісгоспі (Anonimous, 2017a, 2017b). Під час аналізу до уваги брали виділи, де сосна звичайна є головною породою.

Статистичний аналіз даних здійснювали за допомогою пакету програм MS Excel. Відповідність розподілу соснових насаджень за складом, віком і повнотою в осередках короїдного всихання та загалом у лісовому фонді визначали з використанням графічного аналізу та обчислення тетрахоричного показника зв'язку, вірогідність якого оцінювали за критерієм $\chi^{2}$ (Atramentova \& Utevskaya, 2008).

Результати та обговорення. Аналіз даних стосовно динаміки всихання соснових лісів ДП "Володимирецьке ЛГ" свідчить про неухильне збільшення площ осередків (табл.). Площа соснових насаджень, охоплена вибірковими санітарними рубками (ВСР), збільшилася від 252,5 га у 1-му кварталі до 579,5 га у 4-му, а за рік сягала 1718,9 га. Осередки продовжували поширюватися у межах виділів. Частка площі осередків від площі виділу, де проводили вибіркові санітарні рубки, зросла від 24,4 \% у 1-му кварталі до 56,3 \% у 4-му кварталі. Хоча площа насаджень, де проведено вибіркові санітарні рубки, у 2017 р. перевершувала площу, охоплену суцільними санітарними рубками (ССР), можна очікувати збільшення площі останніх у 2018 p.

Табл. Річна динаміка та структура площі санітарно-оздоровчих заходів (СО3) у соснових лісах ДП "Володимирецьке ЛГ"

\begin{tabular}{|c|c|c|c|c|c|c|c|}
\hline \multirow{2}{*}{$\begin{array}{c}\text { Квар- } \\
\text { тал } \\
\text { року }\end{array}$} & \multicolumn{3}{|c|}{ Площа, га } & \multicolumn{2}{|c|}{$\begin{array}{c}\text { Частка від площі } \\
\text { виділу, \% }\end{array}$} & $\begin{array}{c}\text { Частка від } \\
\text { площі всіх } \\
\text { СО3 }\end{array}$ \\
\cline { 2 - 8 } & ВСР & ССР & Разом & ВСР & ССР & ВСР & ССР \\
\hline \multicolumn{7}{|c|}{ Усі санітарно-оздоровчі заходи } \\
\hline 1 & 252,5 & 127,7 & 380,2 & 24,4 & 10,4 & 66,4 & 33,6 \\
\hline 2 & 408,0 & 121,6 & 529,6 & 39,2 & 11,2 & 77,0 & 23,0 \\
\hline 3 & 478,9 & 138,4 & 617,3 & 48,1 & 9,6 & 77,6 & 22,4 \\
\hline 4 & 579,5 & - & 579,5 & 56,3 & - & 100,0 & 0,0 \\
\hline Разом & 1718,9 & 387,7 & 2106,6 & 41,9 & 10,3 & 81,6 & 18,4 \\
\hline у т.ч. санітарно-оздоровчі заходи в осередках короїдів \\
\hline 1 & 2,6 & 9,3 & 11,9 & 17,8 & 16,4 & 21,8 & 78,2 \\
\hline 2 & 308,6 & 93,3 & 401,9 & 39,6 & 11,6 & 76,8 & 23,2 \\
\hline 3 & 421,8 & 138,4 & 560,2 & 48,0 & 9,6 & 75,3 & 24,7 \\
\hline 4 & 579,5 & - & 579,5 & 56,3 & - & 100,0 & 0,0 \\
\hline Разом & 1312,5 & 241,0 & 1553,5 & 48,6 & 10,4 & 84,5 & 15,5 \\
\hline
\end{tabular}

Примітка: ВСР-вибіркові санітарні рубки; ССР-суцільні санітарні рубки; СО3 - санітарно-оздоровчі заходи.

Осередки всихання лісів, яке спричинили переважно короїди, у 1-му кварталі становили тільки 3,1 \% (1,0\% для ділянок, охоплених вибірковими санітарними рубками, і 7,3 \% - охоплених суцільними санітарними рубками). Вже у другому кварталі ця частка перевищила $75 \%$, у третьому кварталі сягала 90,8 \% (88,1\% - за ВCP і $100 \%$ - за ССР), а у четвертому - $100 \%$.

Інтенсивне збільшення площ осередків шкідників, спроможних до розвитку в декількох поколіннях, а саме верхівкового та шестизубчастого короїдів, є характерним наприкінці червня, коли дерева активно заселяє по- томство жуків, які зимували, а пізніше - потомство сестринського покоління (Meshkova et al., 2017). Останнє заселення дерев короїдами, потомство яких може успішно завершити розвиток і вилетіти наступної весни, відбувається у вересні, але їхня чисельність значно менша, ніж весняного покоління (Meshkova et al., 2015). Тому наростання у вересні, а тим більше у грудні, площі осередків, де призначені санітарно-оздоровчі заходи, можна пояснити запізненим виявленням осередків і витратами часу на узгодження планів санітарно-оздоровчих заходів.

Оскільки більшість осередків усихання соснових лісів ДП "Володимирецьке ЛГ" були пов'язані з масовим розмноженням короїдів (див. табл.), у подальших розрахунках використовували дані стосовно сумарної площі санітарно-оздоровчих заходів.

Аналіз розподілу площі соснових насаджень лісгоспу за часткою сосни у складі свідчить про майже рівномірне зростання цього показника від $0,4 \%$ за трьох одиниць сосни у складі до $13,7 \%$ за дев'яти одиниць сосни у складі (рис. 1). Решта 50,3 \% площі припадає на чисті соснові насадження.

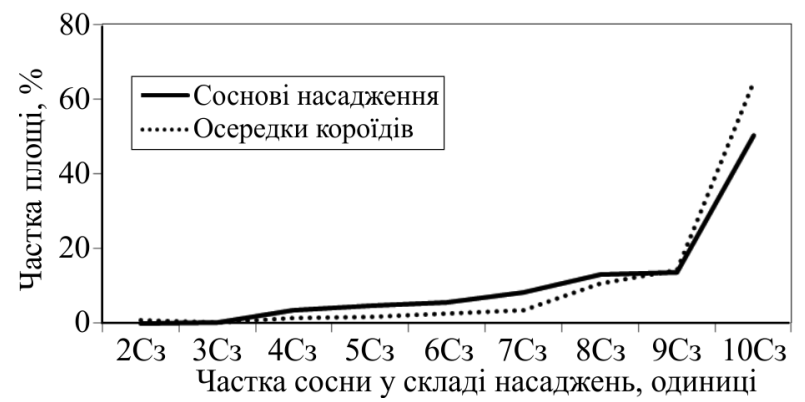

Рис. 1. Розподіл площі всіх соснових насаджень і осередків короїдів за часткою сосни звичайної у складі (ДП "Володимирецьке ЛГ")

В осередках короїдів частка площі чистих соснових насаджень сягає $64,6 \%$, а частка площі насаджень із часткою сосни від 4 до 8 одиниць менша, ніж у всіх деревостанах $(1,4-10,6 \%)$.

Статистичний аналіз підтвердив переважну приуроченість осередків короїдів до чистих соснових насаджень $\left(\chi_{\text {факт. }}^{2}=130,9 ; \chi_{0,05}^{2}=3,8\right)$. Одержані дані узгоджуються 3 відомостями щодо більшої стійкості мішаних насаджень до будь-яких негативних дій, зокрема до заселення шкідниками (Andreieva, Zymaroyeva, 2016).

У віковій структурі соснових насаджень ДП "Володимирецьке ЛГ" яскраво виділяється період V-VIII класів віку, на який припадає 62,0 \% площі всіх соснових насаджень і 90,9 \% площі осередків короїдів (рис. 2).

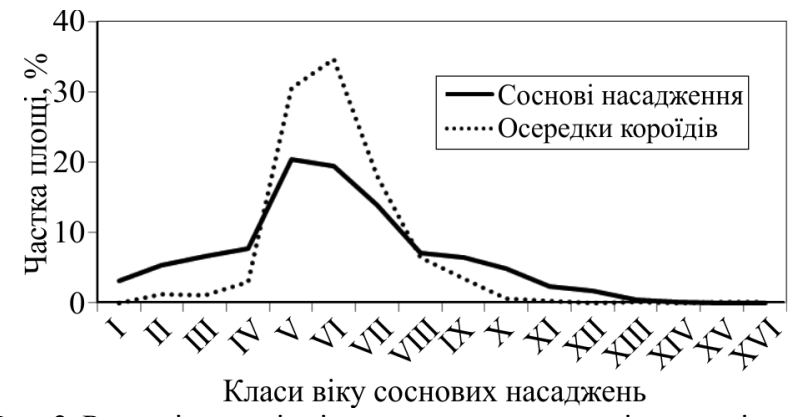

Рис. 2. Розподіл площі всіх соснових насаджень і осередків короїдів за класами віку (ДП "Володимирецьке ЛГ")

У решти класів віку частка площі осередків короїдів поступається частці площі соснових лісів. Виявлені за- 
кономірності підтверджено статистично $\left(\chi_{\text {факт. }}^{2}=540,9\right.$; $\left.\chi_{0,05}^{2}=3,8\right)$. Якщо звузити інтервал до V-VII класів віку, то принадність таких насаджень для короїдів підтверджено ще дужче $\left(\chi_{\text {факт. }}^{2}=655,6 ; \chi_{0,05}^{2}=3,8\right)$. Одержані дані дають змогу рекомендувати проведення нагляду за поширенням осередків короїдів у регіоні переважно в насадженнях саме V-VII класів віку.

У розподілі лісового фонду ДП "Володимирецьке ЛГ" за відносною повнотою простежено переважання високоповнотних соснових насаджень (рис. 3). Так соснові насадження 3 відносною повнотою 0,7-1,0 становлять $80,9 \%, 3$ повнотою $0,8-1.0-45 \%$, а середня зважена повнота - 0,73 одиниці. Водночас в осередках короїдів насадження з відносною повнотою 0,7-1,0 становлять $72,4 \%$, 3 повнотою $0,8-1,0-27,4 \%$, а середня зважена повнота - 0,7 одиниці.

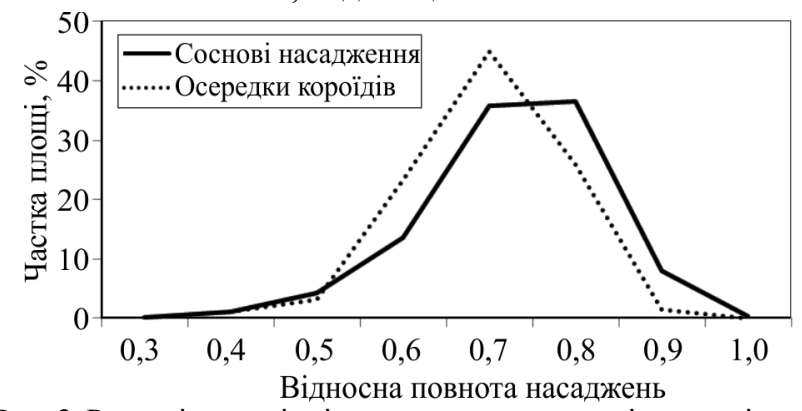

Рис. 3. Розподіл площі всіх соснових насаджень і осередків короїдів за відносною повнотою (ДП "Володимирецьке ЛГ")

Зіставлення розподілу всіх соснових насаджень i осередків короїдів за відносною повнотою з урахуванням усього діапазону цього показника (від 0,3 до 1,0 одиниці) не виявляе статистично достовірних різниць $\left(\chi_{\text {факт. }}^{2}=10,6 ; \chi_{0,05}^{2}=14,1\right)$. Водночас під час зіставлення вибірки насаджень із повнотою не менше 0,8 різниці виявляються достовірними $\left(\chi_{\text {факт. }}^{2}=201,4 ; \chi_{0,05}^{2}=3,8\right)$, причому залежність має зворотний знак: чим більшою $\epsilon$ відносна повнота насаджень, тим меншою $є$ ймовірність виникнення в них осередків короїдів. Такий висновок узгоджено з відомостями стосовно більшої принадності для шкідників насаджень із меншою повнотою (Andreieva \& Zymaroyeva, 2016).

Висновки. Площа всихаючих соснових насаджень ДП "Володимирецьке ЛГ" на кінець 2017 р. перевищила 2000 га. Частка площі осередків короїдів у площі всихаючих соснових насаджень зросла від 3,1 \% у першому кварталі до 75 \% у другому, до 90,8 \% у третьому та до $100 \%$ у четвертому. Чисті соснові насадження становлять 50,3 \% від площі всіх насаджень лісгоспу, де сосна є головною породою, і 64,6 \% від площі осередків короїдів. У віковій структурі соснових насаджень лісгоспу на V-VIII класи віку припадає 61,1% від площі всіх соснових насаджень і 90,9\% від площі осередків короїдів. Середня зважена повнота соснових насаджень ДП "Володимирецьке ЛГ" становить 0,73 одиниці, а в осередках короїдів - 0,7 одиниці. Статистично підтверджено приуроченість осередків короїдів до чистих середньоповнотних соснових насаджень V-VIII класів віку.

\section{Перелік використаних джерел}

Andreieva, O. Y. (2016). Stovburovi shkidnyky v oseredkakh usykhannya sosnovykh nasadzhen' DP "Zhytomyrs'ke LH" Zhytomyrs'koyi oblasti [Stem pests in the foci of pine stands decline in the State Enterprise "Zhytomyr Forest Economy" of
Zhytomyr region]. The Bulletin of Kharkiv National Agrarian University. Series "Phytopathology and Entomology", 1-2, 3-9. [In Ukrainian].

Andreieva, O. Y. (2017). Sanitarnyy stan i rist sosnovykh nasadzhen' v oseredkakh yikhn'oho vsykhannya u DP "Zhytomyrs'ke LH" [Health condition and growth of pine stands in the foci of their drying at the State Enterprise "Zhytomyr Forest Economy"]. Naukovi chytannya - 2017, 3-7. Zhytomyr: Vyd-vo "Zhytomyrs'kyy natsional'nyy ahroekolohichnyy universytet". [In Ukrainian)].

Andreieva, O. Y., \& Zymaroyeva, A. A. (2016). Osoblyvosti poshyrennya mikozu sosny zvychaynoyi u lisovykh nasadzhennyakh Zhytomyrs'koho Polissya. [Peculiarities of spread of Scots pine mycosis in the forest stands Zhytomyr Polissya]. Naukovi chytannya - 2016, 125-129. Zhytomyr: Vyd-vo "Zhytomyrs'kyy natsional'nyy ahroekolohichnyy universytet". [In Ukrainian].

Anonimous. (2017). Report materials about the spread of diseases and pests in the State Specialized Forest Protective Enterprise "Rivnelisozahyst". 70 p. [In Ukrainian].

Anonimous. (2017). Statistical data on sanitary measures in the forest fund of Rivne region. Retrieved from: http://www.rivnelis.gov.ua/material/614. [In Ukrainian].

Atramentova, L. A., \& Utevskaya, O. M. 2008. Statisticheskiye metody v biologii. Gorlovka [Statistical methods in biology]. 148 o. [In Russian].

Balabukh, V. O., Zhyla, S. M., Orlov, O. O., \& Yaremchenko, O. A. (2013). Vrazlyvi ekosystemy Polis'koho pryrodnoho zapovidnyka ta yoho okolyts' $v$ umovakh hlobal'noho poteplinnya: problemy ta shlyakhy vyrishennya [Vulnerable ecosystems of Polissya natural reserve and its environs in conditions of global warming: problems and ways of solving]. Kyiv: "NVP Interservis Ltd". 92 p. [In Ukrainian].

Colombari, F., Schroeder, M. L., Battisti, A., \& Faccoli, M. (2013). Spatio-temporal dynamics of an Ips acuminatus outbreak and implications for management. Agricultural and Forest Entomology, 15, 34 42. https://doi.org/10.1111/j.1461-9563.2012.00589.x

Davydenko, K., Vasaitis, R., \& Menkis, A. (2017). Fungi associated with Ips acuminatus (Coleoptera: Curculionidae) in Ukraine with a special emphasis on pathogenicity of ophiostomatoid species. European Journal of Entomology, 114, 77-85. https://doi.org/10.14411/eje.2017.011

Koval' I. M., Bolohov, O. V., Nusbaum, S. A., Yuzvyns'kyy, H. A. (2015). Radial'nyy pryrist duba zvychaynoho ta yasena zvychaynoho yak indykator stanu lisovykh ekosystem $\mathrm{v}$ umovakh Novohrad-Volyns'koho fizyko-heohrafichnoho rayonu [Radial increment of European oak and European ash as an indicator of forest ecosystem condition in the conditions of Novograd-Volyn physic-geographic region]. Forestry, \& Forest Melioration, 126, 202-211. [In Ukrainian].

Meshkova, V. L. (2017). Evaluation of harm (injuriousness) of stem insects in pine forest. Scientific Bulletin of UNFU, 27(8), 101-104. https://doi.org/10.15421/40270816

Meshkova, V. L., Kochetova, A. I., \& Zinchenko, O. V. (2015). Verkhivkovyy koroyid Ips acuminatus (Gyllenhal, 1827): Insecta: Coleoptera: Scolytinae u Pivnichno-Skhidnomu Stepu Ukrayiny [The pine engraver beetle Ips acuminatus (Gyllenhal, 1827) (Coleoptera: Curculionidae: Scolytinae) in the NorthEastern Steppe of Ukraine]. The Kharkov Entomol. Soc. Gaz., XXIII, 2, 64-69. [In Ukrainian].

Meshkova, V. L., Kochetova, A. I., Zinchenko, O. V., \& Skrylnik Yu. Ye. (2017). Biology of multivoltine bark beetles species (Coleoptera: Scolytinae) in the North-Eastern Steppe of the Ukraine. The Bulletin of Kharkiv National Agrarian University. Series "Phytopathology and Entomology", 1-2, 117-124.

Metodychni rekomendatsiyi. (2011). Metodychni rekomendatsiyi shchodo obstezhennya oseredkiv stovburovykh shkidnykiv lisu [Methodical recommendations for survey of forest stem pest foci]. Responsible author Meshkova, V. L. Kharkiv: URIfFM. 27 p. [In Ukrainian]. 
Turko, V. M., Vyshnevskyi, A. V., Siruk, Yu. V., \& Pecheniuk, Ye. P. (2016). Spreading diseases and pests in the Forests of Rivne region. Scientific Bulletin of UNFU, 26(5), 170-177. [In Ukrainian].
Vyshnevskyi, A. V., \& Turko, V. M. (2018). The spread of diseases in Volyn region forests. Scientific Bulletin of UNFU, 28(1), 51-54. https://doi.org/10.15421/40280110

Е. Ю. Андреева, А. И. Гузий, А. В. Вишневский Житомирский национальный агроэкологический университет, г. Житомир, Украина

Исследованы особенности распространения усыхания сосны обыкновенной (Pinus sylvestris L.) в очагах вершинного (Ips acuminatus (Gyllenhal, 1827)) и шестизубчатого (Ips sexdentatus (Boerner, 1767)) короедов (Curculionidae, Scolytinae) в лесах Государственного предприятия "Володимирецкое лесное хозяйство" Ровенского областного управления лесного и охотничьего хозяйства. Установлено, что площадь усыхающих сосновых насаждений лесхоза в течение 2017 г. возросла и превысила 2000 га к концу года. Долевое участие площади очагов короедов в площади усыхающих сосновых насаждений увеличилась с 3,1 \% в первом квартале до 75 \% во втором, 90,8 \% в третьем и 100 \% в четвертом. Обнаружено, что чистые сосновые насаждения составляют 50,3\% площади всех насаждений лесхоза, в которых сосна является главной породой, и 64,6 \% площади очагов короедов. Выяснено, что в возрастной структуре сосновых насаждений лесхоза на V-VIII классы возраста приходится 61,1 \% площади всех сосновых насаждений и 90,9\% площади очагов короедов. Рассчитано, что средневзвешенная полнота сосновых насаждений лесхоза составляет 0,73 единицы, а в очагах короедов - 0,7 единицы. Статистически подтверждена приуроченность очагов короедов к чистым среднеполнотным сосновым насаждениям V-VIII классов возраста.

Ключевые слова: усыхание; состав; возрастная структура; полнота.

O. Yu. Andreieva, A. I. Guzii, A. V. Vyshnevskyi

Zhytomyr National Agroecological University, Zhytomyr, Ukraine

\section{SPREAD OF BARK BEETLES FOCI IN PINE STANDS OF RIVNE POLISSYA}

Health condition of Scots pine (Pinus sylvestris L.) is worsening in many regions due to climate change and anthropogenic impact, which is favourable for bark beetles outbreaks. Therefore, the purpose of our research was to reveal the peculiarities of pine decline foci spread due to attacks of pine engraver beetle (Ips acuminatus (Gyllenhal, 1827)) and six-toothed pine bark beetle (Ips sexdentatus (Boerner, 1767)) (Curculionidae, Scolytinae)) in the forests of Volodymyretske Forest Enterprise of Rivne Regional Administration of Forest and Hunting Management. Research included statistical and comparative analysis of database of forest fund of the Ukrderzhlisproekt State Enterprise, the data of forest pathological survey of pine stands in Volodymyretske Forest Enterprise and reports on sanitary fellings in 2017. Statistical analysis was carried out with the help of MS Excel. Tetrachoric correlation was evaluated to compare pine stands distribution by stand composition, age and stocking density in the foci of bark beetles and in other pine stands, and the reliability was assessed by $\chi^{2}$ criterion. The area of declining pine stands in this Forest Enterprise exceeded 2,000 hectares by the end of 2017. Percentage of bark beetles foci area in the whole area of declining stands increased from $3.1 \%$ in the first year quarter up to $75 \%$ in the second quarter, up to $90.8 \%$ in the third quarter and up to $100 \%$ in the fourth quarter. It was found that pure pine stands comprise $50.3 \%$ from all stands of the forest enterprise, where pine is the main forest forming species, and $64.6 \%$ from bark beetles foci area. Confinement of bark beetles foci to pure pine stands is statistically confirmed. We defined that pine stands of 40-80 years old make up $62 \%$ of all pine stands area and $90.9 \%$ of bark beetles foci area. Percentage of bark beetles foci in the rest age classes is proved to be less than percentage of pine forest area, which is statistically confirmed. Pine stands with density of stocking $0.7-1.0$ make up $80.9 \%$, with density of stocking $0.8-1-45 \%$. The stands with density of stocking 0.7-1.0 make up 72.4\%, with density of stocking $0.8-1-27.4 \%$ in bark beetles foci. The weighted average density of stocking in pine stands of forest enterprise is 0.73 , and it is 0.7 in bark beetles foci. Confinement of bark beetles foci to pure pine stands of $40-80$ year old with middle density of stocking was statistically confirmed.

Keywords: forest decline; species composition; age structure; density of stocking. 